\title{
PRESENT CLINICAL APPLICATIONS OF TO THE PREVENTION OF ISCHAEMIC HEART DISEASE
}

\author{
By J. F. BRock, D.M., F.R.C.P. \\ Professor of Medicine, University of Cape Town and Groote Schuur Hospital
}

The most significant point to the clinician about the advances surveyed in this symposium is that there has been in the last decade a complete reorientation of attitude towards the chances of effective action for the prevention of ischaemic heart disease. Atherosclerosis was previously regarded, together with its effects, as an uncontrollable manifestation of ageing. To-day there are strong reasons for believing, at least in the case of coronary atherosclerosis that the evolution of its effects can be effectively delayed. Among the principal reasons for this optimism are the epidemiological data showing evidence that in the last few decades myocardial infarction has become more and more prevalent in ever younger age groups among the privileged sections of western civilization. At the same time it has been shown that the less privileged sections within the western cultures are affected less and that the whole or greater part of many non-western and underprivileged communities remain remarkably free. These epidemiological facts justify optimism since so definite a trend in the privileged groups must presumably be due to recently operating, and therefore, preventable environmental factors.

Before proceeding to the consideration of diet, some other methods of management or treatment must briefly be considered. The time-honoured principles of moderation and healthy living still apply and must be regarded as basic. Moderation in smoking and in eating can reasonably be advocated; physical relaxation, recreation, and the resolution of internal tensions may be of great importance. At the same time the development of an invalid mentality by unnecessary restrictions must be carefully avoided. In this connection recreational physical activity for those in sedentary occupations can be urged, and should be carried out to the limit of reasonable tolerance even by those who suffer from angina pectoris following infarction. Among the more recent methods mention must be made at least of anticoagulants, oestrogen therapy, intramuscular injections of magnesium sulphate, sitosterol, nico- tinic acid and pyridoxine. These are all recommended for the prevention of further myocardial infarction. The remedies for intractable angina are legion.

The demonstration that a variety of unsaturated oils of vegetable and marine origin in doses of from 50 to 75 grammes per day, have the capacity to lower serum cholesterol for long periods has led to many commercial attempts to capitalize on low-dose fractions or concentrates of these oils. Compared with the minimum doses of most of the oils which have been proved to be effective in lowering the serum cholesterol level the doses recommended by the makers (at a considerable price) would appear to be ' homeopathic.'

There are various methods, medicinal, radios therapeutic and surgical for the partial ablation of thyroid function and consequent reduction of metabolic rate. These all have the disadvantage of raising the serum cholesterol and are not likely to be favoured except for the seriously disabled patient.

Finally, there are various surgical manoeuvres for increasing the lumen of narrowed arteries or for encouraging or establishing a collateral circulation.

Most of the above methods can be combined with dietary therapy. There will probably be no disagreement that the patient-at-risk who is obese should gradually reduce his calorie intake so as to reduce his weight at least to the lower range for his height, age and sex. Apart from this, there has been interest in the last few years in diets designed to lower the serum cholesterol by altering the quantity and quality of the dietary fat. The theoretical justification for this dietary principle has been dealt with exhaustively by the author (Brock, 1958). Four postulates were advanced for discussion and found to be reasonable in the present state of knowledge. It was concluded that if the postulate be accepted as reasonable, "then it is logical to conclude that the incidence of coronary occlusive episodes in people at risk could be reduced by modification of diet, 
particularly if they lead to sustained reduction of the serum cholesterol. This tentative conclusion does not imply that unsuitable diets are the only, or even the most important, cause of coronary heart disease; it implies only that dietary modification can improve life expectation in people at risk.' A rational basis for this treatment has been provided in the demonstration that certain unsaturated oils increase the excretion of cholesterol as cholic acid several-fold (Lewis, 1958). It is therefore suggested that people at risk should reduce their total fat to something of the order of 25 to 30 per cent. of calories and should substitute to a reasonable extent certain unsaturated oils of vegetable and marine origin for at least a part of their saturated fat intake; i.e. animal fats and any fats which have been artificially hydrogenated. Such a diet can with a little trouble be made palatable and free from nuisance value to the patient and his family (Gordon and Brock, 1958).

It is recognized that the diet consumed by privileged western communities who have a high incidence of ischaemic heart disease differs in many respects, other than in quality and quantity of fat, from the diets of uhderprivileged communities in whom the disease is uncommon.
Any of these other differences might be contributory, but the only difference which has yet been shown to have a rational causative basis, through its effect on serum lipid levels, is that which underlies the recommendation for dietary modification of quantity and quality of fat. In particular carbohydrates, proteins and cellulose have comparatively little effect (Gordon et al., 1958).

It should be emphasized that it is at present just as likely that the beneficial effect of this type of dietary modification is exerted through the prevention of thrombotic occlusive episodes as through its effect on serum lipid levels. It is further emphasized that because of the uncertainties and apparent conflicts which underlie the whole story, the time is not yet ripe for any general advice to populations at large on the consumption of fats in relation to atherogenesis in general. Action on an incompletely proven dietary theory is, however, justifiable in the case of myocardial infarction since it is a serious disease, with increasing prevalence. Dietetics has been a rich field for quackery and a hypothesis, however responsible, must not be dressed up to look like a fact. To-day's remedies may be replaced to-morrow by new knowledge.
MESSINGER, W. J., POROSOWSKA, Y., and STEELE, J. M. (1950), Arch. intern. Med., 86, I89.

MULLER, G. L. (1930), Amer. F. med. Sci., 179, 316.

OLIVER, M. F., and BOYD, G. S. (1953), Clin. Sci., 12, 217.

OLSON, R. E., VESTER, J. W., GURSEY, D., DAVIS, N., and LONGMÁN, D. (1958), Amer. F. clin. Nutr., 6, 3 10.

ORMA, E., KARVONEN, M., KEYS, A., and BROZEK, J. (1958), Fed. Proc., 17, 120.

PARSONS, W. B. Jnr., and FLYNN, J. H. (1957), Circulation, I6, 499 .

POINDEXTER, C., and BRUGER, M. (1935), Arch. intern. Med., 56,884 .

POMERAN7E, J., GOALWIN, A., and SLOBODY, L. B. (1957), Circulation, 16, 481 .

RALLI, E. P., KUHL, W. J. Jnr., GERSHBERG, H., BECK, E. M., STREET, E. R., and LAKEN, B. (1956), Metabolism, 5, 270.

RILEY, F. P., and STEINER, A. (1957), Circulation, 16, 723.

ROSENMAN, R. H., and FRIEDMAN, M. (1957), Ibid., 16, 931.

SANDLER, A., and MCGREGOR, M. (1958), S. Afr. med. $\mathcal{F}$., 32,697 .

SCHAEFER, L. E., ADLERSBERG, D., and STE்INBERG, A. G. (1958), Circulation, 17, 537.
SCRIMSHAW, N. S., BALSAM, A., and ARROGAVE, G. (1957), Amer. F. clin. Nutr., 5, 629 .

SCRIMSHAW, N. S., TRULSON, M., TEJADA, C., HEGSTED, D. M., and STARE, F. J. (1957), Circulation, 15, 805 .

SINCLAIR, H. M. (1956), Lancet, i, 387.

SPERRY, W. E. (1937), f. biol. Chem., 117, 39r.

STARKE, H. (1950), Amer. F. Med., 9, 494.

TAYLOR, H. L., ANDERSON, J. T., and KEYS, A. (1957), Proc. Soc. exp. Biol. (N.Y.), 95, 383.

TOOR, M., KATCHALSKY, A., AGMON, J., and ALLABOUF, D. (1957), Lancet, i, 1270.

TURNER, K. B., and STEINER, A. (1939), f. clin. Invest., 18, 45. WALKER, A. R. P., and ARVIDSON, V. B. (1954), Ibid., 33, 1358.

WALKER, A. R. P., and BERSOHN, I. (1957), S. Afr. med. F., suppl.' 'Medicine in South Africa,' p. 106.

WALKER, W. J., LAWRY, E. Y., LOVE, D. E., MANN, G. V., LEVINE, S. A., and STARE, F. J. (1953), Amer. F. Med., 14,654 .

WERTLAKE, P. T., WILCOX, A. A., HALEY, M. I., and PETERSON, J. E. (1958), Proc. Soc. exp. Biol. (N.Y.).

WILKINSON, C. F. Jnr., HAND, E. A., and FLIEGELMAN, M. T. (1948), Ann. intern. Med., 29, 676.

YOUNG, C. M., RINGLER, I., and GREER, B. J. (1953), f. Amer. diet. Ass., 29, 890. 